\title{
Mere touching imagery promotes purchase intention through increased psychological ownership
}

Sayo Iseki (Graduate School of Environmental Studies, Nagoya University, iseki.sayo@e.mbox.nagoya-u.ac.jp)

Shinji Kitagami (Graduate School of Environmental Studies, Nagoya University, kitagami@cc.nagoya-u.ac.jp)

\section{商品を触るイメージが商品の所有感や購買意図に及ぼす影響}

井関紗代 (名古屋大学大学院環境学研究科)

北神 慎司 (名古屋大学大学院環境学研究科)

\section{要約}

商品を購入する際、その商品を「触る」という行為は、非常に重要な役割を果たしている。その理由の一つとして、ただ 商品を触るだけで、自分の所有物ではないにも関わらず、「自分の物であるような感覚」、すなわち「所有感」が生じるか らであることがわかっている。しかし、オンラインショップなどの普及に伴い、購買意思決定の際に、商品を触ることが できない場面が急増している。先行研究では、実際に商品に触れることができない状況において、目を閉じて商品を「触 るイメージ」をするだけで、その商品に対する、所有感が高まることが示されている。本研究では、この触るイメージが 所有感を高める効果は、安い商品と高い商品という価格帯の違いに関わらず、一様に生じるのか、また、所有感が高まる ことにより、購買意図を促進するのか、という点について検証した。その結果、触るイメージが商品の所有感を高める効 果は、商品の価格帯の違いに関わらず頑健であることが明らかとなった。また触るイメージは、商品に対する「コントロー ル感」と所有感を通して、間接的に購買意図を高めることも示された。このことから、市場において、顧客獲得のために、 所有感を高めることは有益であり、その方略の一つとして、触るイメージの想起が非常に有効であると考えられる。

\section{Key words}

haptic imagery, psychological ownership, purchase intention, physical control, endowment effect

\section{Introduction}

Consumers tend to touch products before deciding whether to buy them and may even be reluctant to make a purchase when they are unable to touch them. Does touch determine consumers' preferences and purchase intention? If so, is there a substitute for touch that has a similar facilitative effect? These answers would have important implications for understanding shopping behaviors especially when actual touching is not possible (e.g., online shopping). The present study investigated whether haptic imagery-imagining touching an object and thinking about how it feels - affects purchase intention for various objects.

Actual touch influences valuation because it leads to increased psychological ownership of products (Peck \& Shu, 2009): the feeling that something is one's own, regardless of actual/ legal ownership (Pierce, Kostova, \& Dirks, 2003). This emerging concept in consumer psychology is associated with the wellresearched endowment effect: people value owned items more than those that they do not own (Kahneman, Knetsch, \& Thaler, 1990; Knetsch \& Sinden, 1984; Thaler, 1980); that is, owners quote a higher price that they are willing to accept when parting with an item than they are willing to pay to acquire it (Kahneman et al., 1990). Even just touching an object increases psychological ownership that then produces the endowment effect, regardless of actual ownership (Peck \& Shu, 2009; Shu \& Peck, 2011). Further, consumers are more willing to buy a product when they can touch it than when they cannot (Peck \& Shu, 2009; Reb \& Connolly, 2007; Wolf, Arkes, \& Muhanna, 2008). These findings suggest that touch plays a major role in purchase intention.

A touchable commodity is not always available; for example, when shopping online or by catalog, consumers are unable to feel merchandise prior to purchase. A crucial question for marketing research is whether an alternative to physical touch exists. Peck, Barger, and Webb (2013) found that imagining touching an object with closed eyes increased psychological ownership in a manner similar to actual touch. Haptic imagery involves imagining touching and holding an object in one's hands, and thinking about how it feels. The effect is not observed when a person imagines touching an object with their eyes open. Peck et al. (2013) demonstrated that touching an object — actual and imagined, with eyes closed - resulted in a greater sense of physical control over the object compared to when participants did not touch the object at all or imagined touching it with their eyes open. Further, this greater feeling of physical control increases psychological ownership (Peck et al., 2013). Indeed, Pierce et al. (2003) theorized that psychological ownership increases as a primary function of the extent to which a person (a) feels that he/ she can control an object (b) invests the self into an object, and (c) is knowledgeable about and familiar with an object.

In their pioneering study, Peck et al. (2013) demonstrated that haptic imagery can substitute for physical touch since it increases psychological ownership. According to Grewal, Krishnan, Baker, and Borin (1998), purchase intention is a reliable pre- 
dictor of actual purchase. Intention refers to the amount of effort one is willing to exert to attain a goal (Fishbein \& Ajzen, 1975) and the intention to engage in a certain course of action logically precedes actual performance of the behavior (Ajzen, 2008). Considering that haptic imagery can increase psychological ownership (Peck et al., 2013), and psychological ownership produces the endowment effect (Shu \& Peck, 2011), it is expected that these relationships would facilitate purchase intention; however research has not explored whether haptic imagery increases purchase intention through increased psychological ownership.

Peck and Shu (2009) examined a similar phenomenon, the impact of ownership imagery on valuation. In their study, participants in the ownership imagery condition were instructed to imagine taking the object home and were asked where they would keep it and what they would do with it. Ownership imagery is more concrete and specific than haptic imagery and involves considerable elaboration. Applying Peck and Shu (2009)'s theory to marketing practice inevitably involves providing consumers with detailed instructions, resulting in more demonstrative, specific, and limited imagination.

In Kamleitner's (2011) survey and scenario study on the context in which objects are strongly desired by consumers, product imagery spontaneously elicited a sense of ownership that mediated the positive association between imagery and attitudes toward products. Kamleitner (2011) concluded that ownership simulations - imagining what it is like to own the product - may be a key determinant of consumer decisions. However, simulations of ownership differ from haptic imagery. Moreover, these findings may be applicable to specific desired objects, and may not be generalizable across commodities.

Kamleitner and Feuchtl's (2015) study regarding the impact of haptic imagery is most relevant to these research questions. Positive correlations between the degree of imagery elaboration (the sensory simulation of experiences) and psychological ownership, and between psychological ownership and attachment/attitudes were observed. In addition, considering that Kamleitner and Feuchtl (2015) used three high-priced objects (i.e., a steam shower, coffee maker, and car), the findings may not be applicable to other products.

Moreover, prior studies about the link between imagery and psychological ownership (e.g., Peck \& Shu, 2009; Kamleitner, 2011; Kamleitner \& Feuchtl, 2015) have not explored whether imagery affects purchase intention through increased psychological ownership although purchase intention is a reliable predictor of actual purchase (Grewal et al., 1998).

There remain two unanswered questions. Can haptic imagery — rather than detailed imagery — affect purchase intention by replacing actual touch? If so, this could be applied to marketing practice; if not, it demonstrates the limits of the use of imagery in marketing (i.e., a detailed explanation rather than haptic imagery is necessary). Second, is the effect of haptic imagery on psychological ownership (and purchase intention) applicable to different objects? Considering that haptic imagery is of par- ticular relevance to online shopping, the present experimental procedure simulated this experience using photographic stimuli instead of actual objects (e.g., Peck et al., 2013).

This study examined whether haptic imagery affects purchase intention via psychological ownership across high- and lowpriced objects. ANOVAs were conducted to examine the relationships between haptic imagery and purchase intention. In addition, SEM was performed to explain the relationship between physical control, familiarity, psychological ownership, valuation, and purchase intention. The conceptual model (see Figure 1) included haptic imagery in the first step, the relationship between physical control and psychological ownership in the second step (based on prior studies: Pierce et al., 2003; Peck et al., 2013), and purchase intention as the final dependent variable since it reliably predicts actual purchase (Grewal et al., 1998). Despite the weak theoretical justification for their inclusion in the model, it was expected that (a) familiarity would influence psychological ownership (Pierce et al., 2003), (b) psychological ownership would increase valuation (Peck \& Shu, 2009), and (c) valuation would positively influence purchase intention (Grewal et al., 1998).

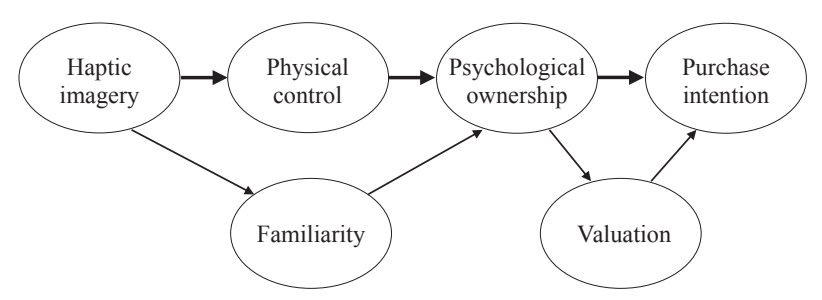

Figure 1: Conceptual model of the relationship between haptic imagery and purchase intention

Note: Bold lines indicate the main predicted paths.

\section{Methods}

\subsection{Participants and Design}

This study was approved by the university's ethical review board. The 118 undergraduate students (74 women and 44 men), aged 18-28 years $(M=19.2, S D=1.27)$, provided prior written informed consent and were tested as part of a classroom activity. The sample's power was 0.93 for independent t-tests $(\alpha=.05)$ with an effect size (Cohen's $d$ ) of 0.65 (i.e., effect size of ownership imagery on valuation from Peck \& Shu, 2009). Participants were assigned to either the "haptic-imagery" (with eyes closed) or "no-imagery" condition. A 2 (haptic vs. no imagery) $\times 2$ (low vs. high price) mixed design was used, with imagery as a between-subjects measure and price as a repeated measure.

\subsection{Materials}

Photographs of 12 objects were used as stimuli: six low-priced objects (kooshball, mug, stuffed dog, neck warmer, wooden spoon, and towel handkerchief) and six high-priced objects (rug, lacquerware bowl, cushion, blanket, leather gloves, and bathrobe). Participants were shown one object per page in a booklet-like format on 
an online shopping website. The photograph appeared at the center of the page, with the name above the photograph, and an adjective such as "high-class" for high-priced objects to allow participants to estimate the price of the object (high/low).

Each of the five dependent variables - physical control, familiarity, psychological ownership, valuation, and purchase intention-used a 7-point Likert scale (1 "strongly disagree" to 7 "strongly agree"; see Table 1). Pierce, Kostova, and Dirks' (2001) psychological ownership scale was adapted for use with Japanese populations. The physical control scale and psychological ownership scale have demonstrated reliability in consumer behavior research (Peck et al., 2013). The procedure for valuation was adapted from Peck and Shu (2009): participants were instructed to guess and select the price of the object from 10 alternatives (in 50-Yen increments and 500-Yen increments for low- and high-priced objects, respectively).

Table 1: Scales and reliability coefficients

\begin{tabular}{lc}
\hline \multicolumn{1}{c}{ Scales } & Cronbach's $\alpha$ \\
\hline Physical control (Peck, Barger, \& Webb, 2013) & \\
When evaluating the object, I felt as though I & .98 \\
could move it & \\
When evaluating the object, I had physical control & \\
over it & .82 \\
\hline Familiarity & \\
I am familiar with this object. \\
I don't feel an affinity to this object. \\
\hline Psychological ownership (Pierce, Kostova, \& Dirks, \\
2001) \\
I feel like this object is mine \\
I feel a personal ownership of the object \\
I feel like I own this object \\
\hline Purchase intention \\
I think I want to buy this object
\end{tabular}

Note: The second familiarity scale is reverse coded.

\subsection{Procedure}

Participants were first presented the photograph for 30 s and were given $1 \mathrm{~min}$ to consider whether they would buy it or not. During this period, participants in the haptic-imagery condition were instructed to close their eyes, imagine touching and holding the object in their hands, and think about how it felt. Participants in the no-imagery condition did not receive this instruction and were only asked to consider whether they would buy it or not. All participants were asked to complete the questionnaire immediately after items were presented. This procedure was repeated for all 12 stimuli, the order of which was randomized across participants and controlled between conditions. Scores on each scale were averaged before performing a series of two-way ANOVAs for dependent variables with price as a repeated measure.

\section{Results}

\subsection{Effects of haptic imagery}

A main effect of imagery was observed for physical control $\left(F(1,116)=57.89, p<.001, \eta p^{2}=.33\right)$ and psychological ownership $\left(F(1,116)=12.94, p<.001, \eta p^{2}=.10\right)$. A main effect of price was found for physical control $(F(1,116)=31.95, p<.001$, $\left.\eta p^{2}=.22\right)$, familiarity $\left(F(1,116)=96.57, p<.001, \eta p^{2}=.45\right)$, psychological ownership $\left(F(1,116)=46.72, p<.001, \eta p^{2}=.29\right)$, and valuation $\left(F(1,116)=7117.96, p<.001, \eta p^{2}=.98\right)$. None of the interactions were significant. That is, the effect of haptic imagery on physical control and psychological ownership was robust regardless of price. Additionally, participants rated low-priced objects as more familiar than high-priced objects, regardless of imagery. The observed significant main effect of price on valuation may be attributable to the different scale ranges (see Figure 2).

\subsection{Structural equation modeling}

As part of the explanatory analysis, imagery (haptic imagery
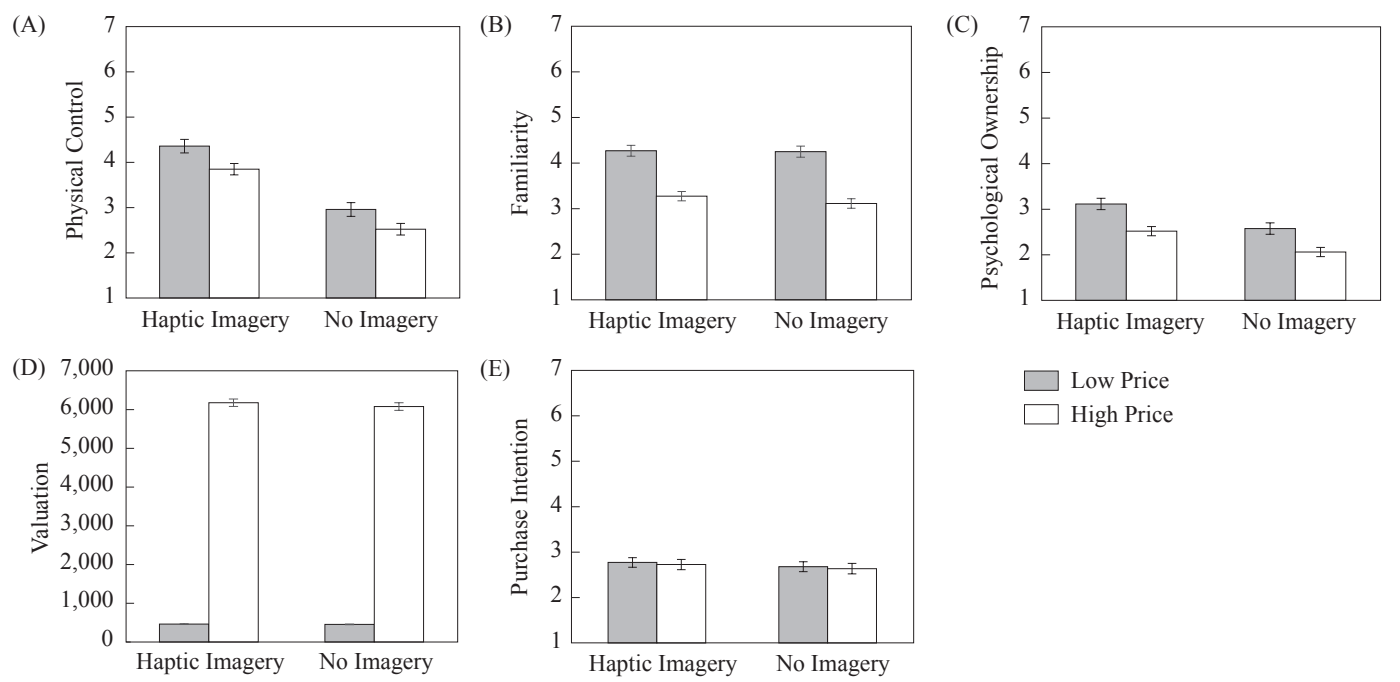

Figure 2: Mean scores of dependent measures according to imagery and price range.

Note: Error bars are standard errors. 
$=1$, no imagery $=0$ ) and purchase intention were included in the SEM. As demonstrated in Table 2, all dependent variables were significantly correlated with each other except for valuation.

SEM was conducted using AMOS 23. The maximum likelihood method was used for estimation. Cut-off scores to determine acceptable model-fit included comparative fit index (CFI) values $>.90$ (Bentler, 1990) and root mean square error of approximation (RMSEA) values $<.10$ (Browne, Cudeck, Bollen, \& Long, 1993; Tabachnick \& Fidell, 2007).

The model shown in Figure 3 demonstrated acceptable fit $\left(\chi^{2}\right.$ $(13)=24.00, p=.031)$, CFI (.99), and RMSEA (.085; $90 \%$ con-

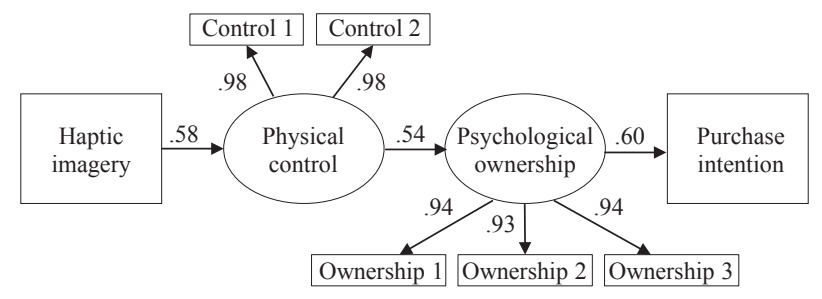

Figure 3: The final model

Notes: All standardized path coefficients were statistically significant at $p<.001$. Control 1 and 2 refer to the two physical control scales. Similarly, Ownership 1, 2, and 3 refer to psychological ownership scales. fidence interval $(\mathrm{CI}): .025-.138, p=.133)$. All path coefficients were statistically significant at $p<.001$.

The model revealed that psychological ownership had a direct effect on purchase intention and physical control, and psychological ownership mediated the relationship between haptic imagery and purchase intention. The model with valuation and familiarity demonstrated poorer fit (see Table 3).

\section{Discussion}

In this study, haptic imagery produced higher levels of physical control and psychological ownership than when imagery was not elicited, regardless of item price. Peck et al.'s (2013) finding that haptic imagery facilitates psychological ownership for low-priced objects was generalizable to high-priced objects. To the best of the authors' knowledge, this is the first study to demonstrate that haptic imagery has an indirect effect on purchase intention through physical control and psychological ownership. While Shu and Peck (2011) have shown that the sense of ownership can trigger a strong endowment effect, which they expected would lead to greater purchase intention, the indirect effect of haptic imagery mediated by psychological ownership had not been demonstrated. Although a direct effect

Table 2: Pearson's correlation coefficients between dependent variables

\begin{tabular}{lrrrcccc}
\hline & $M$ & $S D$ & 1 & 2 & 3 & 4 & 5 \\
\hline 1. Physical control & 3.43 & 1.19 & - & & & & \\
\hline 2. Familiarity & 3.58 & 0.61 & $.36^{* *}$ & - & & & \\
\hline 3. Psychological ownership & 2.57 & 0.79 & $.54^{* *}$ & $.57^{* *}$ & - & & \\
\hline 4. Valuation & 3287.05 & 380.03 & .18 & .07 & -.03 & - & \\
\hline 5. Purchase intention & 2.70 & 0.66 & $.23^{* *}$ & $.42^{* *}$ & $.58^{* *}$ & .07 & - \\
\hline
\end{tabular}

Note: $* * p<.01$.

Table 3: Coefficients and standard errors of all paths

\begin{tabular}{|c|c|c|c|c|c|c|c|c|c|c|c|c|}
\hline \multirow{3}{*}{ Path } & \multicolumn{9}{|c|}{ Unadopted model } & \multirow{2}{*}{\multicolumn{3}{|c|}{$\begin{array}{c}\text { Adopted model } \\
\text { Without familiarity and } \\
\text { without valuation }\end{array}$}} \\
\hline & \multicolumn{3}{|c|}{$\begin{array}{c}\text { With familiarity and } \\
\text { with valuation }\end{array}$} & \multicolumn{3}{|c|}{$\begin{array}{l}\text { With familiarity and } \\
\text { without valuation }\end{array}$} & \multicolumn{3}{|c|}{$\begin{array}{l}\text { Without familiarity and } \\
\text { with valuation }\end{array}$} & & & \\
\hline & Coefficients & $S E$ & $p$ & Coefficients & $S E$ & $p$ & Coefficients & $S E$ & $p$ & Coefficients & $S E$ & $p$ \\
\hline Haptic imagery $\rightarrow$ Physical control & 1.38 & 0.18 & $* * *$ & 1.38 & 0.18 & $* * *$ & 1.36 & 0.18 & $* * *$ & 1.36 & 0.18 & $* * *$ \\
\hline Haptic imagery $\rightarrow$ Familiarity & 0.11 & 0.13 & .41 & 0.10 & 0.13 & .41 & & & & & & \\
\hline Physical control $\rightarrow$ PO & 0.24 & 0.05 & $* * *$ & 0.24 & 0.05 & $* * *$ & 0.35 & 0.05 & $* * *$ & 0.34 & 0.05 & $* * *$ \\
\hline Familiarity $\rightarrow$ PO & 0.60 & 0.11 & $* * *$ & 0.60 & 0.11 & $* * *$ & & & & & & \\
\hline $\mathrm{PO} \rightarrow$ Valuation & -16.90 & 49.83 & .73 & & & & -15.62 & 47.42 & .74 & & & \\
\hline $\mathrm{PO} \rightarrow$ Purchase intention & & & & 0.52 & 0.07 & $* * *$ & & & & 0.52 & 0.07 & $* * *$ \\
\hline Valuation $\rightarrow$ Purchase intention & 0.00 & 0.00 & .43 & & & & 0.00 & 0.00 & .43 & & & \\
\hline Physical control $\rightarrow$ Control 1 & 1.00 & & & 1.00 & & & 1.00 & & & 1.00 & & \\
\hline Physical control $\rightarrow$ Control 2 & 0.97 & 0.04 & $* * *$ & 0.97 & 0.04 & $* * *$ & 0.97 & 0.04 & $* * *$ & 0.97 & 0.04 & $* * *$ \\
\hline Familiarity $\rightarrow$ Familiarity 1 & 1.00 & & & 1.00 & & & & & & & & \\
\hline Familiarity $\rightarrow$ Familiarity 2 & 0.83 & 0.13 & & 0.82 & 0.13 & $* * *$ & & & & & & \\
\hline $\mathrm{PO} \rightarrow$ Ownership 1 & 1.00 & & & 1.00 & & & 1.00 & & & 1.00 & & \\
\hline $\mathrm{PO} \rightarrow$ Ownership 2 & 1.07 & 0.06 & $* * *$ & 1.07 & 0.06 & $* * *$ & 1.07 & 0.06 & $* * *$ & 1.08 & 0.06 & $* * *$ \\
\hline PO $\rightarrow$ Ownership 3 & 0.97 & 0.05 & $* * *$ & 0.98 & 0.05 & $* * *$ & 0.98 & 0.05 & $* * *$ & 0.99 & 0.05 & $* * *$ \\
\hline
\end{tabular}

Notes: PO/Psychological ownership; Coefficients/path coefficients; $* * * p<.001$. 
Table 4: Fit statistics of models

\begin{tabular}{lccccccccc}
\hline \multicolumn{1}{c}{ Model } & \multicolumn{1}{c}{$\chi^{2}$} & $(d f)$ & GFI & AGFI & NFI & CFI & RMSEA & AIC & BIC \\
\hline With familiarity and with valuation & 130.08 & $(32)$ & .83 & .72 & .87 & .90 & .162 & 176.08 & 239.81 \\
\hline With familiarity and without valuation & 61.18 & $(24)$ & .91 & .84 & .94 & .96 & .115 & 103.18 & 161.36 \\
\hline Without familiarity and with valution & 88.60 & $(19)$ & .85 & .72 & .89 & .89 & .177 & 122.60 & 169.70 \\
\hline Without familiarity and without valuation (adopted) & 24.00 & $(13)$ & .95 & .88 & .97 & .99 & .085 & 54.00 & 95.56 \\
\hline
\end{tabular}

Notes: GFI: Goodness of fit index; AGFI: Adjusted goodness of fit index; NFI: Normed fit index; CFI: Comparative fit index; RMSEA: Root mean square error of approximation; AIC: Akaike information criterion; BIC: Bayesian information criterion.

was not observed, physical control and psychological ownership mediate this relationship. According to MacKinnon, Lockwood, Hoffman, West, and Sheets (2002), one can still discuss indirect effects even in the absence of direct effects; yet, indirect effects should be interpreted with caution. While other models with and without familiarity and valuation were examined, this relationship - mediated by physical control and psychological ownership_demonstrates good fit (see Table 4).

In addition, prior studies which have shown the link between imagery and psychological ownership (e.g., Peck \& Shu, 2009; Kamleitner, 2011; Kamleitner \& Feuchtl, 2015) have not examined whether imagery affects purchase intention through increased psychological ownership although purchase intention is a reliable predictor of actual purchase (Grewal et al., 1998). Scholars in marketing have recently begun expressing an interest in psychological ownership (Jussila, Tarkiainen, Sarstedt, \& Hair, 2015). Research on this topic is in early stages, and there is a need for a comprehensive model of psychological ownership as it relates to the purchase of objects and services. The model which this study provided could fulfill such a need.

Studies on psychological ownership in work organizations (Pierce \& Jussila, 2011; Pierce et al., 2001, 2003) identified psychological ownership as rooted in four human needs: (a) efficacy and effectance, (b) self-identity, (c) having a place, and (d) stimulation. These needs are seen as the motivational forces that serve to set individuals on their path toward psychological ownership. In the context of marketing, these motivations could be seen as a force driving customers into attempts to take control of products which they may or may not come to own legally (Jussila et al., 2015). This study also showed that the association between control and psychological ownership is robust and indicated that haptic imagery is one of strategies to meet such human needs.

Considering that the indirect effect was observed across different items, this study proposes that haptic imagery can substitute actual touching; however, this effect is weak. Compared to other forms of detailed imagery (e.g., ownership imagery, Peck \& Shu, 2009; imagery through concrete scenarios, Spears $\&$ Yazdanparast, 2014), haptic imagery has greater applicability. However, the experimental design of this study does not allow a direct comparison of haptic imagery to mere imagery (of anything rather than the target object). Therefore, the dominance of haptic-imagery over mere imagery still could be debated. Additionally, this study did not consider participants' traits and abilities. The authors' next research needs to test individual differences in detecting and recalling vividness of imagery (e.g., VVIQ; Marks, 1973) and how they influence our variables.

The practical implications of this complex relationship should be considered. Kamleitner and Feuchtl (2015) noted that increased psychological ownership depends on the extent of imagery elaboration; the more knowledge a consumer retrieves when elaborating the image of an object, the greater the sense of psychological ownership. Therefore, imagery elaboration is key to psychological ownership. This is consistent with Peck and Shu's (2009) observation of the positive effect of detailed imagery (ownership imagery) on object valuation. Thus, advertising strategies that use haptic imagery (rather than detailed instructions) and pictures to facilitate imagery elaboration could be more effective. Further, Brasel and Gips (2014) found that compared to selecting objects with a mouse, touchscreen use leads to stronger psychological ownership during online shopping, particularly for products with higher haptic importance (e.g., sweatshirts); haptic imagery may be especially useful for developing advertising strategies for such objects.

Factors that inhibit the indirect effect of haptic imagery on purchase intention should be considered. In this study, psychological ownership was lower for high-priced objects compared to low-priced objects, and purchase intention scores for highpriced objects demonstrated a floor effect, implying that haptic imagery may be less effective for high-priced objects. Spears and Yazdanparast (2014) suggest that consumers' imagination may be suppressed when preferred haptic sensory information is absent and when the situation for making a purchase is unambiguous (e.g., ambiguous: upcoming party; unambiguous: upcoming regularly scheduled meeting), thereby reducing the reliance on episodic memory. In particular, haptic information is relevant to sports/exercise equipment, electronics, and furniture (Grohmann, Spangenberg, \& Sprott, 2007; McCabe \& Nowlis, 2003; Peck, 1999). Collectively, this suggests that haptic imagery may not be effective for high-priced objects with low haptic importance.

Future research needs to examine whether haptic imagery is effective for services and other intangible products. For example, Lessard-Bonaventure and Chebat (2015) found that psychological ownership facilitated by touching increases the willingness to pay for an extended warranty only if perceived financial risk is low. Although marketing research has focused on psychological ownership of objects, Lessard-Bonaventure 
and Chebat (2015) demonstrated that the effect of psychological ownership extends to object-related services. Therefore, does psychological ownership positively influence purchase intention for abstract, intangible products (e.g., insurance)? Considering that haptic imagery is strongly associated with psychological ownership, this facilitative influence on services should be explored. Furthermore, actively haptic information is processed through routes close to the ones leading to the frontal robe of our brain (Botvinick \& Braver, 2015). This suggests that haptic imagery was processed "actively" so that it influenced intention (e.g., purchase intention) in our study. In sum, these possibilities should be examined in future research.

\section{References}

Ajzen, I. (2008). Consumer attitudes and behavior. In C. P. Haugtvedt, P. M. Herr, \& F. R. Cardes (Eds.), Handbook of consumer psychology (pp.525-548). New York: Lawrence Erlbaum Associates.

Bentler, P. M. (1990). Fit indexes, Lagrange multipliers, constraint changes and incomplete data in structural models. Multivariate Behavioral Research, 25(2), 163-172.

Botvinick, M. \& Braver, T. (2015). Motivation and cognitive control: from behavior to neural mechanism. Psychology, 66(1), 83.

Brasel, S. A. \& Gips, J. (2014). Tablets, touchscreens, and touchpads: How varying touch interfaces trigger psychological ownership and endowment. Journal of Consumer Psychology, 24(2), 226-233.

Browne, M. W., Cudeck, R., Bollen, K. A., \& Long, J. S. (1993). Alternative ways of assessing model fit. Sage Focus Editions, 154, 136.

Fishbein, M. \& Ajzen, I. (1975). Belief, attitude, intention and behavior: An introduction to theory and research. Reading, MA: Addison-Wesley.

Grewal, D., Krishnan, R., Baker, J., \& Borin, N. A. (1998). The effect of store name, brand name and price discounts on consumers' evaluations and purchase intentions. Journal of Retailing, 74(3), 331-352.

Grohmann, B., Spangenberg, E. R., \& Sprott, D. E. (2007). The influence of tactile input on the evaluation of retail product offerings. Journal of Retailing, 83(2), 237-245.

Jussila, I., Tarkiainen, A., Sarstedt, M., \& Hair, J. F. (2015). Individual Psychological Ownership: Concepts, Evidence, and Implications for Research in Marketing. Journal of Marketing Theory and Practice, 23(2), 121-139.

Kahneman, D., Knetsch, J. L., \& Thaler, R. H. (1990). Experimental tests of the endowment effect and the Coase theorem. Journal of Political Economy, 1325-1348.

Kamleitner, B. (2011). When imagery influences spending decisions. Zeitschrift für Psychologie/Journal of Psychology, 219(4), 231-237.

Kamleitner, B. \& Feuchtl, S. (2015). "As if it were mine”: Imagery works by inducing psychological ownership. Journal of Marketing Theory and Practice, 23(2), 208-223.

Knetsch, J. L., \& Sinden, J. A. (1984). Willingness to pay and compensation demanded: Experimental evidence of an unexpected disparity in measures of value. The Quarterly Journal of Economics, 507-521.

Lessard-Bonaventure, S. \& Chebat, J. -C. (2015). Psychological ownership, touch, and willingness to pay for an extended warranty. Journal of Marketing Theory and Practice, 23(2), 224-234.

MacKinnon, D. P., Lockwood, C. M., Hoffman, J. M., West, S. G., \& Sheets, V. (2002). A comparison of methods to test mediation and other intervening variable effects. Psychological Methods, 7(1), 83-104.

Marks, D. F. (1973). Visual imagery differences in the recall of pictures. British journal of Psychology, 64(1), 17-24.

McCabe, D. B. \& Nowlis, S. M. (2003). The effect of examining actual products or product descriptions on consumer preference. Journal of Consumer Psychology, 13(4), 431-439.

Peck, J., Barger, V. A., \& Webb, A. (2013). In search of a surrogate for touch: The effect of haptic imagery on perceived ownership. Journal of Consumer Psychology, 23(2), 189-196.

Peck, J. \& Shu, S. B. (2009). The effect of mere touch on perceived ownership. Journal of Consumer Research, 36(3), 434-447.

Peck, J. (1999). Extraction of haptic properties: Individual characteristics and stimulus characteristics (Unpublished doctoral dissertation). University of Minnesota, Minneapolis.

Pierce, J. L. \& Jussila, I. (2011). Psychological ownership and the organizational context: theory, research evidence, and application. Edward Elgar Publishing.

Pierce, J. L., Kostova, T., \& Dirks, K. T. (2001). Toward a theory of psychological ownership in organizations. Academy of Management Review, 26(2), 298-310.

Pierce, J. L., Kostova, T., \& Dirks, K. T. (2003). The state of psychological ownership: Integrating and extending a century of research. Review of General Psychology, 7(1), 84-107.

Reb, J. \& Connolly, T. (2007). Possession, feelings of ownership, and the endowment effect. Judgment and Decision Making, 2(2), 107-114.

Shu, S. B. \& Peck, J. (2011). Psychological ownership and affective reaction: Emotional attachment process variables and the endowment effect. Journal of Consumer Psychology, 21(4), 439-452.

Spears, N. \& Yazdanparast, A. (2014). Revealing obstacles to the consumer imagination. Journal of Consumer Psychology, 24(3), 363-372.

Tabachnick, B. G. \& Fidell, L. S. (2007). Using multivariate statistics. Boston, MA: Pearson Education.

Thaler, R. (1980). Toward a positive theory of consumer choice. Journal of Economic Behavior \& Organization, 1(1), 39-60.

Wolf, J. R., Arkes, H. R., \& Muhanna, W. A. (2008). The power of touch: An examination of the effect of duration of physical contact on the valuation of objects. Judgment and Decision Making, 3(6), 476-482

(Received April 7, 2016; accepted May 11, 2016) 